\title{
GRANICA INGERENCJI W SFERĘ INTYMNĄ OSÓB PONIŻEJ 15. ROKU ŻYCIA. ZGODA NIELETNIEGO PONIŻEJ 15. ROKU ŻYCIA NA OBCOWANIE PLCIOWE A SANKCJA Z ART. 200 $\S 1$ KODEKSU KARNEGO
}

\begin{abstract}
Streszczenie. Opracowanie dotyczy przedmiotu ochrony z art. $200 \S 1$ kodeksu karnego, jakim jest wolność seksualna osób poniżej 15. roku życia. Podstawowym jego celem jest udzielenie względnie jednoznacznej odpowiedzi na pytanie, czy w sytuacji, kiedy sprawca jest zaledwie kilka lat starszy od pokrzywdzonego oraz w momencie, gdy ofiara sama inicjuje czynności seksualne dorosły młodociany powinien być karany zgodnie z sankcją z ww. przepisu. Mając na uwadze stale obniżający się wiek inicjacji seksualnej młodzieży, gdy osoba, która nie ukończyła 15. roku życia, dobrowolnie poddała się czynności seksualnej z osobą nieznacznie starszą (powyżej 17. roku życia, ponieważ taką granicę wieku wprowadza kodeks karny, by móc sprawcy przypisać popełnienie czynu zabronionego), powstaje dysonans prawny, moralny i obyczajowy. Z jednej bowiem strony są przepisy penalizujące takie zachowanie, $\mathrm{z}$ drugiej to nieletni sam przekroczył granicę ingerencji w swoją sferę intymną. W sytuacji, gdy ofiara zgadza się na kontakty seksualne albo sama zachęca czy inicjuje obcowanie płciowe lub inną czynność seksualną, neguje to cel, który przyświecał ustawodawcy kryminalizującemu takie zachowania. Tym niemniej przepisy obowiązują, w związku $\mathrm{z}$ czym warto przybliżyć tę tematykę w odniesieniu nie tylko do zachowania nagannego w kontekście prawnym, ale także z punktu widzenia socjologii czy obyczajności.

Słowa kluczowe: obcowanie płciowe, granica wieku zgody, wykorzystywanie seksualne dzieci, wolność seksualna, prawnorelewantna zgoda.
\end{abstract}

\section{WPROWADZENIE}

Granica wieku, w którym osoby nieletnie poddają się obcowaniu płciowemu lub innej czynności seksualnej od kilkunastu lat zdecydowanie się obniża. Jednocześnie sfera życia intymnego nigdy nie była poza zainteresowaniem prawa, w tym prawa karnego. Jest to też obszar badań na gruncie obyczajności, psychologii, seksuologii. Słusznie twierdzi Marian Filar, że obyczajowa, a w szczególności prawna reglamentacja przejawów seksualności i życia seksualnego musi być częścią i pochodną ogólnej reglamentacji uzewnętrznionej społecznie aktywności ludzkiej, zbudowaną na wspólnych podstawach, kierującą się wspólnymi zasadami i podlegającą wspólnym prawom o uniwersalistycznym

\footnotetext{
*Uniwersytet Wrocławski, Wydział Prawa, Administracji i Ekonomii, diana.szwejser@uwr.edu.pl.
} 
i pozaseksualnym, a właściwie ściślej: ponadseksualnym charakterze (Filar 1985, 13). Sferę intymną posiada każdy człowiek. Każdy też może dobrowolnie wyznaczyć granicę ingerencji w tę sferę. Jej przekroczenie również może nastąpić dobrowolnie, nierzadko jednak dzieje się to wbrew woli pokrzywdzonego. W opracowaniu autorka wskaże, w jakich sytuacjach następuje przekroczenie granicy sfery intymnej pokrzywdzonego, który nie ukończył 15. roku życia oraz jakie są konsekwencje prawne wobec sprawcy przestępstwa z art. 200 $\S 1$ ustawy z dnia 6 czerwca 1997 r. - Kodeks karny (tekst jedn. Dz.U. z 2018 r., poz. 1600; dalej: k.k.), ze szczególnym uwzględnieniem kontaktów seksualnych w sytuacji, gdy sprawcę i ofiarę dzieli nieznaczna różnica wieku. W artykule zostaną również postawione wnioski de lege ferenda.

\section{DYSPOZYCJA ART. $200 \S 1$ KODEKSU KARNEGO}

Nietrudno jest wyobrazić sobie parę, w której różnica wieku między partnerami wynosi 3-5 lat, szczególnie pomiędzy osobami w młodym wieku. Nie budzi również zdziwienia sytuacja, gdy licealista spotyka się z gimnazjalistką czy uczennicą ostatnich klas szkoły podstawowej. Jeżeli jednak przełożymy to na wiek niepełnoletnich, może okazać się, że jedna z osób ma skończone 17 lat, druga niespełna 15. Przekroczenie granicy 15. roku życia przesądza, według polskiego ustawodawcy, o konsekwencjach prawnych ingerencji w sferę intymną nieletniego. Zgodnie bowiem z art. $200 \S 1$ k.k.: „kto obcuje płciowo z małoletnim poniżej lat 15 lub dopuszcza się wobec takiej osoby innej czynności seksualnej lub doprowadza ją do poddania się takim czynnościom lub ich wykonania, podlega karze pozbawienia wolności od lat 2 do lat 12". W zakresie sankcjonowanego zachowania zawiera się więc nie tylko zakaz obcowania płciowego, ale również inna czynność seksualna. W orzecznictwie rozumie się przez to takie zachowanie, niemieszczące się w pojęciu „obcowania płciowego", które związane jest z szeroko rozumianym życiem płciowym człowieka, polegające na kontakcie cielesnym sprawcy z pokrzywdzonym, lub przynajmniej na cielesnym i mającym charakter seksualny zaangażowaniu ofiary, co obejmuje te sytuacje, w których sprawca, zmierzając do pobudzenia lub zaspokojenia swojego popędu, nie tylko dotyka narządów płciowych pokrzywdzonego (choćby przez bieliznę lub odzież), lecz podejmuje również inne czynności w zetknięciu z jego ciałem, np. pieszczoty, pocałunki (wyr. SA w Krakowie z 2 lutego 2015 r., II Aka 12/15, LEX nr 1770344). Nie jest więc wykluczone postawienie komuś zarzutu seksualnego wykorzystywania małoletniego w sytuacji, gdy między sprawcą a ofiarą doszło wyłącznie do pocałunków, a przecież dla ludzi młodych jest to naturalna i podstawowa forma okazywania sobie uczuć. 
Wolność seksualna przysługuje każdemu. Przez wolność seksualną Lech Gardocki rozumie element szeroko rozumianej wolności. Odróżnia od niej obyczajność jako system norm społecznych (głównie moralnych), regulujących zachowania się ludzi w sferze seksualnej, będącą samodzielnym i równorzędnym w stosunku do wolności seksualnej przedmiotem ochrony (Gardocki 1998, 239, 243 i n.) $)^{1}$. Odmiennego zdania jest Witold Świda, który wyraża pogląd, że wolność seksualna jest przejawem obyczajności w dziedzinie płciowej, a więc dotyczy przyjętych w społeczeństwie norm moralnych w tej dziedzinie (Świda 1986, 497-498)². Wolność seksualna jest wyrazem realizacji prawa do prywatności. Prawo do prywatności jest fundamentalną wartością, chronioną zarówno na kanwie prawa międzynarodowego, jak i ustawy zasadniczej Polski. Warto wspomnieć więc o art. 17 Międzynarodowego Paktu Praw Obywatelskich i Politycznych (Dz.U. z 1977 r. Nr 38, poz. 167) $)^{3}$, oraz art. 8 i art. 14 Konwencji o Ochronie Praw Człowieka i Podstawowych Wolności, obowiązującej w Polsce od 19 stycznia 1993 r. (Dz.U. z 1993 r. Nr 61, poz. 284). W polskim prawie, poza wspomnianym już kodeksem karnym, prawo do prywatności zostało zagwarantowane w Konstytucji RP - art. 31, art. 47 ustawy z dnia 2 kwietnia 1997 r. Konstytucja Rzeczypospolitej Polskiej (Dz.U. z 1997 r. Nr 78, poz. 483).

\section{WEZZLOWE ZAGADNIENIA WIEKU ZGODY}

Ukończenie 15 lat traktuje się na gruncie prawa karnego jako wiek zgody czy wiek przyzwolenia, a więc granicę, po przekroczeniu której małoletni może samodzielnie i świadomie decydować o swoim życiu intymnym albo, inaczej mówiąc, jest to minimalny wiek, od którego osoba może wyrażać ważną prawnie zgodę na czynności seksualne z inną osobą. W Polsce ustalenie takiej „linii demarkacyjnej” na dzień ukończenia 15. roku życia nie jest wytworem kodeksu karnego z 1997 r., już bowiem na gruncie kodeksu karnego z 1969 r. wprowadzono przepis dotyczący popełnienia czynu nierządnego (dzisiaj to przestępstwo z art. 200 $\S 1$ k.k.) względem osoby poniżej 15. roku życia. Jak słusznie wskazuje Jarosław Warylewski, było to następstwem założenia, że małoletni poniżej 15. roku życia, podobnie jak osoba niepoczytalna, pozbawiony jest zdolności do wyrażenia prawnie skutecznej zgody na współżycie oraz inne formy aktywności seksualnej (Warylewski 2001, 148). Podobnie kodeks karny z 1969 r. przyjął rozwiązanie granicy wieku 15 lat jednej z osób za wyznacznik karalnego obcowania płciowego ${ }^{4}$.

\footnotetext{
${ }^{1}$ Podobnie Warylewski (2001).

${ }^{2}$ Tak również Filar (1989).

${ }^{3}$ Pakt otwarty do podpisu w Nowym Jorku od dnia 19 grudnia 1966 r., przyjęty w Polsce 18 czerwca $1977 \mathrm{r}$.

${ }^{4} \mathrm{Na}$ marginesie zaznaczyć można tylko, że przyjęcie kryterium wieku za jedyną przesłankę, wyznaczającą karalność lub nie seksualnego zaangażowania, nie przez wszystkich
} 
Granica wieku małoletniego, podlegającego ochronie przed wykorzystaniem seksualnym, jest dyskusyjna. Z jednej strony już pod rządami uprzednio obowiązującego kodeksu karnego postulowano obniżenie granicy wieku małoletniego do lat 14. Poza tym wiek, w którym młodzi ludzie rozpoczynają kontakty seksualne, obniża się - obecnie kilka procent trzynasto- i czternastolatków jest aktywnych płciowo. O ile 60 lat temu obniżenie granicy wieku zgody mogłoby nie mieć wielu zwolenników, o tyle teraz, w dobie wcześniejszego dojrzewania i rozpoczynania aktywności seksualnej wśród młodych ludzi, postulat ten jest coraz częściej wysuwany.

Wyznaczona granica wieku dziecka, podlegającego bezwzględnej ochronie przed seksualnym wykorzystaniem ze strony dorosłych, nie zawsze wynosiła 15 lat. W dawnej Anglii na przykład kontakty seksualne dozwolone były z osobami w wieku powyżej 10 lat. Wiek przyzwolenia jest oczywiście różnie regulowany. Istnieją kraje, np. Meksyk, gdzie w niektórych stanach limit jest obniżony nawet do 12. roku życia, ale wiek ten jest niższy niż w Polsce również w wielu państwach europejskich, jak choćby w Niemczech, Szwajcarii czy we Włoszech i wynosi 14 lat. Z drugiej strony niektórzy przedstawiciele doktryny postulują, by granicę tę podwyższyć nawet do 18 . roku życia ${ }^{5}$. Wówczas karani byliby małżonkowie, którzy uzyskali zgodę na zwarcie małżeństwa przed uzyskaniem pełnoletniości, co prowadziłoby do absurdu. Tymczasem zgoda na wcześniejsze zawarcie małżeństwa przed uzyskaniem pełnoletności powinna być traktowana jako regulacja lex specialis. W takim przypadku o żadnym karaniu mowy być nie może. Argumentem zaś uzasadniającym podniesienie wieku mógłby być wpływ wcześniejszej inicjacji seksualnej na sytuację psychiczną dziecka. Zgodzić się bowiem należy z Kazimierzem Pospiszylem, że doznania seksualne nie tylko dominują nad słabszymi doznaniami, ale także zabarwiają zdecydowaną większość wyborów moralnych, i to nawet takich, które mają pozornie bardzo mały związek z erotyką (Pospiszyl 2005, 58).

Zagadnienie wieku dziecka jest kwestią na tyle istotną, że oddziałuje na jego dwa zasadnicze aspekty. Jako pierwszą płaszczyznę należy wymienić wpływ wykorzystywania seksualnego na późniejszy rozwój ofiary. Powszechne jest myślenie, że im dziecko jest młodsze, tym poważniejsze zaburzenia w jego psychice wywołają przedwczesne kontakty seksualne. Podobny sposób myślenia widać również w wyrokach sądowych, w których wymierza się tym wyższą karę, im

jest akceptowalne. Nie będą bowiem karane osoby, które współżyją płciowo, a są w wieku poniżej prawnie określonej dojrzałości seksualnej. Tymczasem, gdyby przyjąć za kryterium sprawstwo czynu i relację między rówieśnikami, można by było dojść do wniosku, że angażowanie dziecka w kontakty seksualne przez osobę w podobnym wieku także nosi znamiona wykorzystywania. David Finkelhor zaś postulował przyjęcie jako kryterium znacznej różnicy wieku (Finkelhor 1994).

${ }^{5}$ Pogląd taki prezentuje Barbara Kunicka-Michalska (2004, 27-28). Podobne rozwiązanie stara się zaakcentować Andrzej Adamski (2001, 53). 
mniej lat ma dziecko. Ze stanowiskiem takim nie sposób zgodzić się do końca, ponieważ skutki psychiczne wykorzystywania seksualnego nie są czymś wyizolowanym, ale dopiero razem z sytuacją rodzinną, społeczną, osobowością ofiary tworzą całokształt konsekwencji wpływających na emocje dziecka. Drugi aspekt związany z wiekiem ofiary dotyczy sprawcy przestępstw seksualnych. Pedofile bowiem podniecają się nie na samą myśl o dziecku, ale o ofierze w konkretnym wieku, określanym na podstawie wyglądu obiektu seksualnego. Dziesiąta rewizja Międzynarodowej Klasyfikacji Chorób (ICD-10), opracowana przez Światową Organizację Zdrowia, uznaje pedofilię za zaburzenie preferencji seksualnych, klasyfikując ją pod indeksem F65.4. oraz definiując jako kontakty seksualne osoby dorosłej z dziećmi, najczęściej w wieku przed pokwitaniem lub pokwitania. Niektórzy preferują kontakty z dziewczynkami, inni z chłopcami albo są zainteresowani jedną i drugą płciąa . We wcześniejszym opisie ICD-10 z 1993 r. kryterium specyficznym pedofilii był wiek sprawcy: minimum 16 lat i jednocześnie o co najmniej pięć lat więcej niż ofiara. Podobnie pedofilię definiują dwa powszechnie uznawane systemy klasyfikacji chorób i zaburzeń psychicznych: DSM-IV oraz DSM-5 jako jednostkę 302.2.

\section{RATIO LEGIS KARANIA WYKORZYSTYWANIA SEKSUALNEGO MALOLETNIEGO}

Pomimo iż poniższe opracowanie dotyczy przede wszystkim zagadnienia ingerencji w sferę intymną małoletniego, w sytuacji, gdy między ofiarą a sprawcą istnieje niewielka różnica wieku, wspomnieć należy o negatywnych wpływach pedofilii na szeroko rozumianą psychikę ofiary w wieku adolescenckim. Dzieciom bowiem do momentu dojrzewania kształtuje się wiele zachowań, których konsekwencje widoczne będą dopiero w dorosłości. Ciężko jest również wskazać jednoznacznie granicę wieku, od której można bez wahania stwierdzić, że nieletni ma wyrobione wzorce społeczne oraz ukształtowaną psychikę, a jego decyzje dotyczące sfery intymnej są w pełni rozsądne i świadome. Oczywiście w Polsce istnieje pozytywizm prawniczy i polski ustawodawca przyjął jako taką barierę 15 lat, jednakże każdy organizm reaguje na bodźce inaczej, a młodzież dorasta czasem wcześniej, a czasem w późniejszym wieku. Stąd też skutki obcowania płciowego w wieku młodzieńczym mogą być widoczne nieraz dopiero w dorosłym życiu ofiary. Joanna Mierzwińska-Lorencka wyraża pogląd, że

${ }^{6}$ Międzynarodowa Statystyczna Klasyfikacja Chorób i Problemów Zdrowotnych. Rewizja dziesiata ICD-10. [Wytyczne WHO]. 2009. T. 1: World Health Organization, Centrum Systemów Informacyjnych Ochrony Zdrowia. https://www.csioz.gov.pl/fileadmin/user_upload/Wytyczne/ statystyka/icd10tomi_56a8f5a554a18.pdf [dostęp 29.03.2018]. 
od zjawiska wykorzystania seksualnego należy odróżnić pojęcie pedofilii [...]. Najprościej można zdefiniować pedofilię jako podejmowanie aktywności seksualnej z dziećmi lub fantazjowanie o tej aktywności przez osobę dorosłą jako stale preferowany lub wyłączny sposób osiągnięcia podniecenia seksualnego i orgazmu. Wykorzystywania seksualnego mogą się natomiast dopuszczać nie tylko pedofile, ale również osoby, które podejmują kontakty seksualne z dziećmi, ponieważ mają trudność (z różnych powodów) w nawiązaniu kontaktów seksualnych z osobami dorosłymi. Dziecko jest w tym przypadku bardziej dostępnym, łatwiejszym w pozyskaniu partnerem seksualnym, choć nie jest bardziej pożądanym erotycznie obiektem (Mierzwińska-Lorencka 2012, 37).

Pedofilia nierzadko wywołuje uraz psychiczny, objawiający się głównie znacznym obniżeniem samooceny, poczuciem winy, czy depresją, nerwicą. Może negatywnie wpływać na zdolność koncentracji i jakość snu. Niekorzystne konsekwencje zauważyć można również w relacji ze środowiskiem, jak choćby w niewystarczających umiejętnościach utrzymywania trwałych związków, braku lub nadmiernym angażowaniu się w relacje miłosne, podatności na stawanie się ofiarą niewłaściwych zachowań o podłożu seksualnym ze strony innych osób.

Kodeks karny w art. $200 \S 1$ sankcjonuje zachowanie polegające na wykorzystywaniu seksualnym małoletniego poniżej 15. roku życia. Według SCOSAC (Standing Committee On Sexually Abused Children) za dziecko wykorzystywane seksualnie można uznać każdą jednostkę w wieku bezwzględnej ochrony, jeżeli jednostka dojrzała seksualnie przez działania świadome lub przez zaniedbanie swoich społecznych obowiązków, wynikających ze specyficznej odpowiedzialności za dziecko, dopuszcza do zaangażowania dziecka w jakąkolwiek aktywność natury fizycznej, której intencją jest seksualne zaspokojenie osoby dorosłej (SCOSAC 1984). Jest to oczywiście jedna z wielu formułowanych definicji wykorzystywania seksualnego dzieci. Na potrzeby niniejszego artykułu jest ona jednak bardzo przydatna, podobnie jak ta, którą posługuje się Monika Sajkowska. Według WHO wykorzystywanie seksualne dziecka to włączanie dziecka w aktywność seksualną, której nie jest ono w stanie w pełni zrozumieć i udzielić na nią świadomej zgody i/lub na którą nie jest dojrzałe rozwojowo i nie może zgodzić się w ważny prawnie sposób, i/lub która jest niezgodna z normami prawnymi lub obyczajowymi danego społeczeństwa. Z wykorzystywaniem seksualnym mamy do czynienia, gdy taka aktywność wystąpi pomiędzy dzieckiem a dorosłym lub dzieckiem a innym dzieckiem, jeżeli te osoby, ze względu na wiek bądź stopień rozwoju, pozostają w relacji opieki, zależności, władzy. Celem takiej aktywności jest zaspokojenie potrzeb innej osoby (Sajkowska 2002, 7). Gdyby opierać się na literalnym brzmieniu obu tych charakterystyk, nie sposób by było przypisać przestępstwa z art. 200 k.k. osobie pełnoletniej, która jest tylko kilka lat starsza od ofiary swojego czynu, w sytuacji, gdy nieletni poniżej 15 . roku życia sam inicjuje kontakty seksualne lub do nich namawia. $\mathrm{O}$ ile bowiem uznamy nawet, że taka osoba nie jest zdolna w prawnie ważny sposób udzielić 
zgody na czynności seksualne z jej udziałem, o tyle w przypadku faktycznego zaangażowania ofiary w dokonanie kontaktu seksualnego o braku zrozumienia swojego działania mowy być nie może.

\section{PRÓBA OCENY OBOWIĄZUJĄCYCH PRZEPISÓW I WNIOSKI DE LEGE FERENDA}

Przedmiotem ochrony art. $200 \S 1$ k.k. jest wolność seksualna małoletnich, jak również ich prawidłowy rozwój seksualny. Wczesne kontakty seksualne stanowią zagrożenie dla rozwoju psychofizycznego dzieci, w związku z czym szkodliwe są zarówno kontakty małoletniego z dorosłymi, jak i sytuacja obcowania płciowego dwojga małoletnich poniżej 15. roku życia. W tym drugim przypadku nie będzie można jednak stosować przepisów karnych, zgodnie bowiem z art. 10 k.k. odpowiedzialność karną mogą ponosić wyłącznie osoby, które skończyły 17 lat, możliwe natomiast będzie stosowanie środków wobec nieletnich.

W sytuacji, w której osoba powyżej 17. roku życia współżyje z osobą poniżej 15. roku życia, ale różnica wieku między tymi osobami jest niewielka, warto zastanowić się nad dwoma kwestiami: po pierwsze, czy taką osobę w ogóle karać, a po drugie - jeśli karać, to jaka odpowiedzialność takiej osobie grozi. Wskazać można na przykład federalny kodeks karny USA, w którym zapisano, że kontakty seksualne z dziećmi między 12. a 16. rokiem życia są karalne, jeśli osoba, która się w nie angażuje jest o cztery lub więcej lat starsza niż dziecko (Sajkowska 2002, 6). Przechodząc już do konsekwencji prawnych w obecnym stanie prawnym w polskim kodeksie karnym, należy stwierdzić, że czyn taki może zostać uznany za czyn zabroniony o znikomym stopniu społecznej szkodliwości. Jako czynniki o tym świadczące powinno się wymienić: motywację sprawcy zmierzającego do podjęcia kontaktu seksualnego z osobą, która ze względu na podobny wiek jest traktowana przez niego jako naturalny cel dążeń seksualnych; niewielki rozmiar wyrządzonej szkody, związany z faktem, że dojrzałość emocjonalna osoby małoletniej poniżej 15. roku życia przekraczała jej wiek, co przesądza o niewielkim zagrożeniu dla jej rozwoju psychofizycznego; okoliczności czynu, do których należy zaliczyć m.in. fakt, że ofiara na równi ze sprawcą dążyła do podjęcia kontaktu seksualnego. Niestety zgoda czy zachęta małoletniego nie wpływa pozytywnie na brak karalności za przestępstwo z art. 200 k.k., w tym przypadku bowiem nie ma mowy o wyrażeniu przez ofiarę prawnie relewantnej zgody na rozdysponowywanie swoją seksualnością albo na obserwowanie prezentowanej jej czynności seksualnej. W związku z tym sprawcy grozi kara pozbawienia wolności w wymiarze od 2 do 12 lat. Jest to więc występek. Wobec takiego sprawcy możliwe jest złagodzenie kary. Jeżeli natomiast czyn będzie popełniany wielokrotnie przez dłuższy czas i sąd nie zdecyduje się na nadzwyczajne złagodzenie kary, będzie musiał sprawcy, nawet 
młodocianemu, wymierzyć karę minimum dwóch lat pozbawienia wolności. Powoduje to sytuację, w której wobec sprawcy nie można zastosować warunkowego zawieszenia wykonania kary. Nie można jej zamienić na karę wolnościową $\mathrm{z}$ art. 37a k.k., można natomiast orzec karę pozbawienia wolności do 6 lat oraz ograniczenia wolności do dwóch lat, czyli instytucję z art. 37b k.k. Co gorsza, wobec takiego sprawcy nie dojdzie do zatarcia skazania, ponieważ był skazany na karę pozbawienia wolności bez warunkowego zawieszania za przestępstwo przeciwko wolności seksualnej lub obyczajności na szkodę małoletniego poniżej 15. roku życia. Nie można więc wykluczyć, że w wieku 20 lat, po dwuletnim pozbawieniu wolności, wyjdzie sprawca, który w karcie karnej będzie miał na stałe wpisany czyn z art. $200 \S 1$ k.k.

Właśnie na tym polu pojawia się postulat de lege ferenda zastanowienia się nad zmianą przepisu art. $200 \S 1$ k.k. poprzez dodanie typu uprzywilejowanego przestępstwa w sytuacji, gdy między sprawcą a ofiarą istnieje niewielka różnica wieku. Ewentualnie w wyposażenie sądu w instytucje prawne umożliwiające wydanie w takich okolicznościach wyroku warunkowo umarzającego, odstąpienie od wymierzenia kary, a skupienie się na poprawie postawy społecznej takiego oskarżonego poprzez dozór kuratora itp.

Konkludując, popełnienie czynu z art. $200 \S 1$ k.k. wywołuje wiele negatywnych konsekwencji - tak w sferze psychiki ofiary, jak i sankcji prawnych zastosowanych wobec sprawcy. Nie bez znaczenia powinien pozostawać fakt, że z roku na rok granica wieku, w którym młodzi ludzie rozpoczynają współżycie, obniża się. Nierzadko też dojrzałość emocjonalna osób poniżej 15. roku życia jest wyższa od ich faktycznego wieku, co oznacza, że mają one świadomość, czym jest obcowanie płciowe i poddają się jej dobrowolnie. Oczywiście, mając na uwadze ewentualną nowelizację przepisów czy obniżenie wieku zgody, należy pamiętać o tym, że skutki wczesnej inicjacji seksualnej mogą uzewnętrznić się dopiero w dorosłym życiu pod postacią różnego rodzaju zaburzeń emocjonalnych.

\section{BIBLIOGRAFIA}

Adamski, Andrzej. 2001. Przestępczość w cyberprzestrzeni. Prawne środki przeciwdziałania zjawisku w Polsce, na tle projektu Rady Europy. Toruń: Dom Organizatora.

Filar, Marian. 1985. Przestępstwa seksualne w polskim prawie karnym. Toruń: Uniwersytet Mikołaja Kopernika.

Filar, Marian. 1989. „Przestępstwa w dziedzinie stosunków seksualnych”. W System prawa karnego. Red. Igor Andrejew, Leszek Kubicki, Jan Waszczyński. T. 4. Cz. 2: O przestępstwach w szczególności. 149-163. Wrocław: Zakład Narodowy im. Ossolińskich.

Finkelhor, David. 1994. „Current Information on the Scope and Nature of Child Sexual Abuse”. The Future Of Children 4 (2): 31-53.

Gardocki, Lech. 1998. Prawo karne. Warszawa: Wydawnictwo C.H. Beck. 
Kunicka-Michalska, Barbara. 2004. Wybrane problemy przestępstw przeciwko wolności seksualnej i obyczajności popetniane za pośrednictwem systemu informatycznego. Wrocław: Zakład Narodowy im. Ossolińskich.

Mierzwińska-Lorencka, Joanna. 2012. Karnoprawna ochrona dziecka przed wykorzystywaniem seksualnym. Warszawa: Wolters Kluwer.

Międzynarodowa Statystyczna Klasyfikacja Chorób i Problemów Zdrowotnych. Rewizja dziesiąta. ICD-10. [Wytyczne WHO]. 2009. T. 1: World Health Organization, Centrum Systemów Informacyjnych Ochrony Zdrowia. https://www.csioz.gov.pl/fileadmin/user_upload/Wytyczne/ statystyka/icd10tomi_56a8f5a554a18.pdf [dostęp 29.03.2018].

Pospiszyl, Kazimierz. 2005. Przestepstwa seksualne. Geneza postacie, resocjalizacja oraz zabezpieczenia przed powrotnościa. Warszawa: Wydawnictwo Naukowe PWN.

Sajkowska, Monika. 2002. „Wykorzystywanie seksualne dzieci - ustalenia terminologiczne, skala zjawiska, oblicza problemu społecznego". Dziecko Krzywdzone. Teoria. Badania. Praktyka 1: 5-28.

SCOSAC. 1984. Definition of Child Sexual Abuse. London: Standing Committee on Sexually Abused Children.

Świda, Witold. 1986. Prawo karne. Wyd. 3. Warszawa: Państwowe Wydawnictwo Naukowe.

Warylewski, Jarosław. 2001. Przestępstwa przeciwko wolności seksualnej i obyczajności. Rozdziat XXV Kodeksu karnego. Komentarz. Warszawa: Wydawnictwo C.H. Beck.

\title{
Orzecznictwo
}

Wyrok SA w Krakowie z dnia 2 lutego 2015 r., II Aka 12/15, LEX nr 1770344.

\section{Akty prawne}

Konstytucja Rzeczypospolitej Polskiej z dnia 2 kwietnia 1997 r. (Dz.U. z 1997 r. Nr 78, poz. 483).

Konwencja o Ochronie Praw Człowieka i Podstawowych Wolności z dnia 4 listopada 1950 r. ze zm.

(Dz.U. z 1993 r. Nr 61, poz. 284).

Międzynarodowy Pakt Praw Obywatelskich i Politycznych z dnia 19 grudnia 1966 r. (Dz.U. z 1977 r. $\mathrm{Nr} 38$, poz. 167).

Ustawa z dnia 19 kwietnia 1969 r. - Kodeks karny (Dz.U. z 1969 r. Nr 13, poz. 94).

Ustawa z dnia 6 czerwca 1997 r. - Kodeks karny (tekst jedn. Dz.U. z 2018 r., poz. 1600).

\section{Diana Szwejser}

\section{LIMITS OF INTERFERENCE WITH CHILDREN'S INTIMACY LEGAL REGULATION VS. INTIMACY WITHOUT VIOLENCE}

\begin{abstract}
This paper analyses some specific problems under article $200 \S 1$ of the Penal Code. The basic aim of my research was to give a relatively clear answer to the question about penalising an offender when he/she is just several years older than his/her victim or when the victim initiates sexual activities. Taking into consideration the decrease of age in which youths begin sexual initiation, it is important to know what the consequences of it in their emotional sphere are. By referring such observations to the problem of child sexual abuse, there is a dissonance between child's acceptance of incursion in his/her intimacy and legal regulations. Therefore, child sexual abuse is not only a legal problem, but it also has influence on sexuality and the society, morality etc.
\end{abstract}

Keywords: intimacy, limit of incursion, child sexual abuse, sexual freedom, informed consent. 